\title{
The Impact of Applying Good Governance Principles on Job Satisfaction among Public Sector Employees in Jordan
}

\author{
Haitham Ali Hijazi \\ Department of Business, Jerash University, Jerash, Jordan \\ Email: info@hijazi-km.com
}

How to cite this paper: Hijazi, H. A. (2021). The Impact of Applying Good Governance Principles on Job Satisfaction among Public Sector Employees in Jordan. Open Journal of Business and Management, 9, 1-31.

https://doi.org/10.4236/ojbm.2021.91001

Received: November 6, 2020

Accepted: December 5, 2020

Published: December 8, 2020

Copyright (c) 2021 by author(s) and Scientific Research Publishing Inc. This work is licensed under the Creative Commons Attribution International License (CC BY 4.0).

http://creativecommons.org/licenses/by/4.0/

\begin{abstract}
This study aims to investigate the impact of the applying of good governance principles on job satisfaction among employees working in the public sector in Jordan. The study population consisted of all public sector employees who are subject to the Civil Service Code (219,000 employees), where the analysis and sampling unit included all job titles. The study sample size was $384 \mathrm{em}-$ ployees, with 315 returned questionnaires, and 308 questionnaires analyzed after excluding the questionnaires that are not suitable for analysis. The study found a statistically significant impact of applying good governance principles collectively (transparency, justice and equality, accountability, participation, and integrity) in each dimension of job satisfaction separately (salaries and compensations, direct supervision, training programs, promotions, and performance evaluation) to varying degrees. The results showed a statistically significant effect of applying good governance principles on job satisfaction among employees in the public sector in Jordan.
\end{abstract}

\section{Keywords}

Good Governance, Job Satisfaction, Public Sector

\section{Introduction}

At the end of 1970s, many financial and administrative breaches, repeated manifestations of corruption and bribery started to appear in business institutions in several countries like the United States, United Kingdom, Italy, and others. Such breaches happened in Guinness, Barings Futures, Polly Peck International, Maxwell, The International Trade and Credit Bank, Enron, and even in Government Institutions such as the incident in Metropolitan Police Station, among 
others. Those legal and ethical breaches were the main reason for the emergence of what is called today "good governance" or "corporate governance". In order to address these violations and strengthen the governance approach, a set of governance rules and principles were issued, such as Sarbanes-Oxley in the United States, Cadbury Code, United Kingdom Code, and others (Khudir \& Ali, 2019; Matei \& Drumasu, 2015). In 1989, the World Bank studied the reason why developing countries were not realizing development achievements despite the diverse resources possessed by the public sectors that are supposed to be directed towards providing the best services to citizens. It also examined the role and accomplishments of higher administrative leaderships as they are responsible for managing those resources and for the quality of services provided to citizens. The result of the study was "bad governance" (Mazhar and Goraya, 2015), which was the starting point for public sector governance.

Today, both public and private institutions are paying increased attention to the concept of good governance, and are working to adopt it in their work (Channuwong, 2018), due to the positive impact on enabling these institutions to achieve their goals and their competitive advantages, of which the human resource is the basis.

\section{Background}

\subsection{Governance}

To date, no unified definition of governance exists as each researcher defines it from his point of view differently, even though most of these definitions have commonalities within. Fardaus and Khan (2006) define governance as exercising economic, political, and administrative authority to run a country at all levels. Ramakant (2003) defines governance as a decision-making process through which decisions are executed or not. Naveed (1998) describes governance as managing resources, organizing human capital and work groups within associations, bodies, formal and informal organizations, using economic, administrative, political, and social methods. Kempe sees that good governance requires the existence of efficient and accountable political, judicial, administrative, and economic institutions that work on establishing rules that help support and promote growth, protect human rights, respect the Rule of Law, and guarantee people's freedom to participate and have their voices heard in making decisions that affect their lives (Adeogun et al., 2017). Khudir \& Ali (2019) consider corporate governance the guarantee for transparency in the enterprise operations, good management output, efficiency in the products and services provided, as well as a set of good practices derived from good management and accountability of private companies and government institutions.

Adrian Cadbury defines governance as the system through which companies are managed and monitored, while the Australian National Audit Office (ANAO) defines it as the processes by which organizations are managed, monitored and 
owned, referring to Authority, Responsibility, Administration, Management, Guidance, and Controlling within the organization (https://www.anao.gov.au). Meanwhile, Matei and Drumasu (2015) define governance as the method that the organization-public or private-is led and monitored through, with the aim of performing and carrying out its responsibilities successfully. In addition to realizing the added value within the organization and using its available resources efficiently, respecting the rights of all relevant parties, and fulfilling its obligations towards them. Moreover, Papachristou \& Papachristou (Papachristou \& Papachristou, 2014) explain corporate governance in the public sector as administrative procedures and financial resources management and control aimed at satisfying stakeholders and improving the work of government institutions. Grindle (2007) sees that good governance calls for improvements that affect all aspects of the public sector, starting with the institutions that set legislations, the ones that make decisions, and ending with the human resources working in the government sector that make up the government bureaucracy. The World Bank describes governance as the method through which authority is exercised to manage a country's political, economic, and social resources to achieve growth (Kamal and Batool, 2020). Whereas the United Nations Development Program refers to governance as exercising the authority on economic, political, and managerial matters to run a country on all levels (Channuwong, 2018).

\subsubsection{Governance Dimensions}

Studies that examined good governance have indicated that there are several dimensions to it, which are applied in the public and private sectors. These dimensions are: Participation, Rule of Law, Clarification, Responsiveness, Equity and Inclusiveness, Accountability, Result-Oriented, Effectiveness of Roles and Responsibilities, The Promotion of Roles, Capacity Building, Economy Saving, Transparency, Availability of Information, Management Effectiveness and Efficiency, Consensus Orientation, Responsibility, Legitimacy, Integrity, Fairness, Openness, Citizen Voice, Political Stability, Regulatory Quality, Control of Corruption, Virtue, Justice, Strategic Vision, Equity, Risk and Performance Management, Defining Outcomes (Bouckaert and Van de Walle, 2003; Shafi, 2004; Fardaus \& Khan, 2006; Papachristou \& Papachristou, 2014; CIPFA and IFAC in Juiz, et al., 2014; Brinkerhoff and Brinkerhoff, 2015; Matei and Drumasu, 2015; Mazhar and Goraya, 2015; Shahin, 2016; Channuwong, 2018; Gavriluta and Lotos, 2018; Ali, n/a; Khudir \& Ali, 2019; Jamaiudin, 2019; Kamal and Batool, 2020).

\subsubsection{Principles of Governance in the Public Sector}

Nolan Commission has defined the principles of corporate governance in the public sector at the United Kingdom as Selflessness, Integrity, Objectivity, Accountability, Sinceritate, Openness, Honesty, Leadership (Matei and Drumasu, 2015). Butler also defined the dimensions of good governance in the United 
Kingdom public sector as Mission and Vision, Strategy, Leadership, Assurance, Probity and Transparency, and Stewardship. He also created a framework that defines good governance dimensions for public sector institutions in the future in the United Kingdom, to include these dimensions: Citizens, Digital, Place, Policy, Leadership and Culture, Accountability and Partnership, Regulation and Infrastructure, Measurement and Impact (Butler, 2019).

\subsubsection{The Importance of Corporate Governance}

Governance is considered an integrated process, of which the basis is the coordination, with two main parties, the public and private sectors (Kamal and Batool, 2020). Grindle notes that humanity could be better off if organizations were to apply principles of governance (Channuwong, 2018). (Shafi, 2004; Papachristou \& Papachristou, 2014; Khudir \& Ali, 2019) point out that corporate governance is important in the sense that it:

- Helps to set and monitor goals.

- Works on defining leadership role in the organization, and its strategic responsibilities.

- Helps achieve high performance, and improve efficiency and organizational effectiveness.

- Helps create an effective supervisory system.

- Prevents the Board of Directors and senior management from invading the organization.

- Allows minorities who work in the organizations to get fair treatment.

- Improves the level of performance for government institutions.

- Improves the financial situation of the state.

- Enhances the efficiency of government institutions.

- Improves the social life of citizens.

- Provides excellent services.

- Satisfies stakeholders.

- Helps improve citizens' confidence in their government.

- Helps improve the country's image in front of international organizations and markets, thus attracting investments and establishing development projects.

\subsubsection{Public Sector Governance in Jordan}

The number of workers in the public sector in Jordan is 219,000 employees working in 98 government institutions, which vary between ministries, public departments (Civil Service Bureau). Since the 1970s, a series of government initiatives started to take place with the aim of developing the public sector performance in Jordan. In 2014, the government announced a performance development program for the years 2014-2016, which was one of the references for a "Guide to Governance Practices in the Public Sector" that was developed by the Ministry of Public Sector Development, an entity that was in place at the time. The aim of the guide was to define the guidelines that help public sector institu- 
tions in Jordan to apply good governance practices in the sector and reinforce the values of justice, equality, rule of law, anti-corruption, transparency and accountability, in order to preserve public money and achieve quality and excellence in performance (Ministry of Public Sector Development, 2014). This guide defined the objectives that public sector governance in Jordan seeks to achieve, which are as follows:

- Increasing citizens' satisfaction with the services provided by the public sector.

- Achieving the principle of accountability for government departments and their employees, particularly with respect to adhering to laws and regulations.

- Achieving the principle of integrity, justice, and transparency in the use of power and in public money and resources management, and limiting the exploitation of public power for private purposes.

- Achieving the principle of equal opportunities for citizens.

- Achieving the necessary protection for public ownership, considering the interests of the relevant parties.

- Working to achieve strategic national goals, and realizing financial stability for government departments.

- Increasing government organizations capabilities by enhancing and developing organizational performance through continuous monitoring and evaluation.

- Establishing effective systems for managing institutional business risks and mitigating the effects of risks and financial crises.

Accordingly, the guide defined two main bases for public sector governance; efficiency in resources management and guarantee of related parties' rights.

This study investigated more the dimensions of good governance for public sector employees by conducting interviews with them, and found that the following dimensions mattered most for them, and hence were adopted as one of the current variables for this study:

- Transparency: the openness and clarity in the decision-making process and resource allocation. Countries are required to have systems for transparent decision-making, budgeting, and tracking of expenditures (Kaplan et al., 2013). Transparency is also seen as the freedom of information flow, ease of access to those who want to have it, and the obligation to provide sufficient information (Fardaus and Khan, 2006). Additionally, it means that every organization is responsible for providing full satisfactory details to the concerned people, and that all government institutions must ensure the transparency of their decision-making process (Kamal and Batool, 2020).

- Equality and Justice: ensuring that stakeholders' rights are protected (Shafi, 2004). It means integrity grounded on virtue, morals, business ethics, legality, equality, and justice, and is one of the most important elements that lead to an increased organizational satisfaction (Channuwong, 2018).

- Accountability: public sector employees and service providers are subject to accountability for the actions they perform and their effects, and the willingness to accept penalties if these outputs and effects are not achieved due to 
decisions and actions they took (Kaplan et al., 2013; Khudir and Ali, 2019). Accountability also means that the rule of law must be exercised and that anyone who has authority must be held accountable (Kamal and Batool, 2020).

- Participation: the engagement of everyone in the decision-making process, whether directly or indirectly through representatives, making their engagement based on the freedom to participate and speak (Adeogun et al., 2017). The participation of both men and women is considered the building block of good governance in decision-making (Fardaus and Khan, 2006).

- Integrity: is uprightness and honesty and is based on knowledge and education of the person as it is concerned with overseeing public funds and resources and depends on specific measures of behavior and professionalism (Papachristou and Papachristou, 2014). It is a guarantee of honesty, objectivity, and uprightness in managing public resources and organization's issues. Integrity depends on the existence of an effective monitoring system, and on the professionalism and principles of the individuals in charge of the institution (Khudir and Ali, 2019).

\subsection{Job Satisfaction}

The literature indicates that human capital is the critical component in the success of organizations because of its vital role in performance and productivity levels, which cannot be achieved unless circumstances and positive environment exist; that push individuals towards more giving and working, in order to achieve organizational goals. Employees' job satisfaction comes at the forefront of these conditions, and it is the basis of a positive stimulating environment. The higher the level of job satisfaction, the greater the motivation employees have to work, which helps increase productivity and achieve organizational goals, whereas the lower the level of job satisfaction, the more employees' motivation and productivity are affected negatively, and thus on achieving goals (Lezar, 2019).

Locke defines job satisfaction as a positive emotional state of contentment and pleasure stemming from the appreciation of one's work and experience (Voon et al., 2011). Kreis and Brockopp explain it as a feeling associated with self-awareness of fulfilling needs at work (Malik et al., 2010). Spector defines it as the extent to which an individual feels satisfied or dissatisfied with his work (Eslami and Gharakhani, 2012). Whereas (Alamrew et al., 2016) define job satisfaction as feeling happy, fulfilling needs, and working with complete desire; describing how individuals feel about their work. It is also defined as the way that people feel towards their jobs, and that the factors affecting how they feel (negatively or positively) may be related to the procedures and policies of the organization, work conditions, or the personality of the employee (Shahin, 2016). Job satisfaction in the public sector is defined as reflecting the compatibility between needs, individual values, and subsequent job experiences (Perry and Wise, 1990).

Pushpika (2019) indicates that a satisfied individual carries a positive attitude 
toward his work, and an individual who is not satisfied has a negative attitude toward his work. Job satisfaction is considered important to all organizations regardless of their size, nature, and form. Studies by Spector and Chen et al., found that job satisfaction affects the absenteeism rate, work turnover rate, and the psychological distress of individuals (Eslami and Gharakhani, 2012). Lezar (2019) believes that job satisfaction is a behavior that reflects the extent to which an individual accepts the job in all its aspects, and the extent to which how he feels comfortable and happy.

\subsubsection{The Importance of Job Satisfaction}

Levy's study conducted in 2003 (Safadi et al., 2019) indicates that having job satisfaction among workers in organizations would help achieve high performance and high productivity levels, and if the job satisfaction levels are absent or low, it will lead to decrease in productivity and performance levels, and withdrawal behaviors will start appearing among employees. Job satisfaction plays a role in reducing work turnover, laziness, absenteeism, being late for work, and the emergence of health problems among employees, it also increases organizational loyalty; as employees who have job satisfaction show positive attitudes in their homes. It is also seen that job satisfaction helps attract well-qualified individuals, create inventive activities, and increase productivity and stability in work (Cinar and Karcioglu, 2012). Moser notes that the absence of job satisfaction leads to fatigue and low organizational loyalty (Adeogun et al., 2017).

\subsubsection{Job Satisfaction Dimensions}

Studies indicate that there are many dimensions for job satisfaction, including: Promotion, Pay, Working Conditions, Job Security, Work Tasks, Compensations, Leadership Style, Organizational Structure, Organizational Climate, Equitable Rewards, Communications, Needs Fulfillments, Organizational Support, Supervision, Coworkers Superior-Subordinate Communication (Voon et al., 2011; Kumari and Pandey, 2011; Eslami and Gharakhani, 2012; Sukdeo et al., 2017; Decy and Ryan in Karolidis and Vouzas, 2019; Safadi, et al., 2019).

This study investigated the most important dimensions of job satisfaction among public sector employees by conducting interviews with them, and found that the following dimensions mattered most for them, and hence were adopted as one of the current variables for this study:

- Salaries and Compensation Packages: the money that an individual receives has a strong influence in determining job satisfaction (Sukdeo et al., 2017). The employee's satisfaction with their salary (wage) depends on their ability to satisfy their individual requirements and needs, and its suitability compared to the effort exerted and the salaries levels in other organizations; individuals compare the earnings they receive in relation to the input they made with the earnings of other individuals working in the organization in relation to their inputs. If the inputs are equal and the earnings differ, then employees feel unfair, and the result is resentment and dissatisfaction (Belhadef and 
Bouzain, 2019).

- Immediate Supervisors: employees' feeling that they are of interest to their supervisors and are keen to establish a relationship of understanding and harmony with them and help them solve their problems (Belhadef and Bouzain, 2019). Rhoades \& Eisenberger define it as the supervisor's behaviors in helping employees demonstrate the skills, knowledge, and attitudes they gained from training programs (Qureshi \& Bin Ab Hamid, 2017).

- Training Programs: the activities exercised with the aim of acquiring new knowledge or skills to achieve goals ( $\mathrm{Nda} \&$ Fard, 2013). It is a function of human resources management that aims to improve the performance of individuals and groups and is known by several names such as human resource development, and learning and development (Raheja, 2015).

- Promotion: rewards that create an incentive for employees to work optimally, push them to commit and devote themselves to work, and affect their job satisfaction, career mobility, and progression to higher levels (Sukdeo et al., 2017). Promotion depends on the availability of opportunities and the employees' aspirations for promotion being equal to what is available; if the employee's aspirations for promotion are greater than what is available or existing, the less satisfaction he is with his job (Belhadef and Bouzain, 2019).

- Performance Evaluation: methods and processes used by organizations to evaluate their employees' performance (Van Dijk \& Schodl, 2015). Gardner defines it as evaluating the work of an individual with the aim of reaching objective decisions related to the management of personnel affairs in the organization, and identifying their weaknesses and strengths in order to improve their performance (Idowu, 2017). Armstrong also defines it as the process that involves obtaining information on the relative value of the employees, recording the information, and analyzing it (Idowu, 2017). De Nisi \& Pritchard defines it as a process that occurs once or twice a year, through which the dimensions and performance criteria that are used in the evaluation process are determined. This process aims to assess individuals' performance and inform them of their performance levels (De Nisi \& Pritchard, 2006).

\subsubsection{The Relation between Good Governance and Job Satisfaction}

Nmai \& Delle (2014) concluded that good corporate governance is an important and vital issue for organization advancement and positive employee behavior, and that good governance and predicts positively and indicatively employees' job satisfaction. The study also found that setting a good governance system is necessary to derive good employees' behavior. (Sandika, et al., 2016) also concluded that there is a positive and significant relationship between job satisfaction and employees' awareness of good governance at the Sri Lankan Ministry of Agriculture. The study found that the perception of good governance by the respondents led to an increase in their level of job satisfaction. IN another study 
(Oshilim \& Akpesiri, 2015) conducted on the public sector in Nigeria concluded that in order to increase the productivity and integration of employees, the three HS's must be available (Head, Heart, Hand) along with government good governance. Moreover, (Lakshika \& Priyanath, 2018) study found a positive impact of governance on job satisfaction of Supportive Staff at Sabaragamuwa University in Sri Lanka.

In a study conducted by (Alamrew et al., 2016) on the University of Gondar in Ethiopia to investigate the effect of governance on job satisfaction for university employees (including academics and administrators) and on their performance and desire to leave work, the study found that many respondents did not confirm that the university does not practice good governance, and most of them did not feel satisfied with their jobs and have a desire to leave work. To solve this problem, the study recommended that the university should improve its governance. Shahin (2016) conducted a study that aimed to evaluate the impact of good governance indicators for public organizations in improving the level of job satisfaction of their employees. The study was conducted on the faculty and staff of Lorestan University in Iran and found that the application of good governance indicators in the organization will lead to an increase in the level of job satisfaction among employees. Channuwong (2018) notes in his study on government employees in Bangkok that the principles of good governance are positively related to organizational justice, and that the rule of law is highly related to the principle of transparency, which is the most influential in organizational justice.

Another study by (Belhadef and Bouzian, 2019) found that applying sound governance leads to job satisfaction, especially when governance adopts a participatory model that considers all stakeholders and gives human resources special attention. It also found that employees who feel satisfied with their jobs, will be more productive. This indicates that the relationship between corporate governance and job satisfaction is a positive relationship, which improves the performance of employees and the performance of the institution and reduces work incidents and sickness. However, the study conducted by Bordbar \& Saraji (2017) on the Insurance Commission in Iran concluded that there is no positive relationship between corporate governance and employees' frustration, organizational indifference, and organizational opposition, while a positive relationship was found between institutional governance and the increase of employees' motivation, empowerment, and their work teams.

\section{Research Problem/Questions}

The research problem is represented in the following main question:

"What is the effect of applying the principles of good governance on job satisfaction among employees in the public sector in Jordan?"

The following questions emerged from this question:

The first question: To what extent are the principles of good governance, in 
its dimensions (transparency, justice and equality, accountability, participation, integrity) are applied in the public sector in Jordan?

The second question: To what extent is job satisfaction, in its dimensions (salaries and compensation, immediate supervision, training and professional development, promotion, performance evaluation) is applied among public sector employees in Jordan?

The third question: What is the impact of applying the principles of good governance, in its combined dimensions (transparency, justice and equality, accountability, participation, integrity) on achieving job satisfaction, in its combined dimensions (salaries and compensation, direct supervision, training and professional development, promotion, performance evaluation) for public sector employees in Jordan?

\section{Research Hypothesis}

Based on the third research question, the following hypotheses were made:

$\mathrm{H1}$ : There is no statistically significant impact at $(\alpha \leq 0.05)$ that sound corporate governance practices in their wider and all-inclusive context (transparency, equality and justice, accountability, participation, integrity) have been implemented in setting salaries and compensation packages for public sector workers in Jordan.

H2: There is no statistically significant impact at $(\alpha \leq 0.05)$ that sound corporate governance practices in their wider and all-inclusive context (transparency, equality and justice, accountability, participation, integrity) have been implemented in setting the parameters of and managing the relationship between public sector workers and their immediate supervisors in Jordan.

H3: There is no statistically significant impact at $(\alpha \leq 0.05)$ that sound corporate governance practices in their wider and all-inclusive context (transparency, equality and justice, accountability, participation, integrity) have been implemented in designing and delivering training programs for public sector workers in Jordan.

H4: There is no statistically significant impact at $(\alpha \leq 0.05)$ that sound corporate governance practices in their wider and all-inclusive context (transparency, equality and justice, accountability, participation, integrity) have been implemented in the promotion of public sector workers in Jordan.

H5: There is no statistically significant impact at $(\alpha \leq 0.05)$ that sound corporate governance practices in their wider and all-inclusive context (transparency, equality and justice, accountability, participation, integrity) have been implemented in the performance evaluation of public sector workers in Jordan.

$\mathrm{H} 5$ : There is no statistically significant impact at $(\alpha \leq 0.05)$ that sound corporate governance practices in their wider and all-inclusive context (transparency, equality and justice, accountability, participation, integrity) have been implemented in the performance evaluation of public sector workers in Jordan.

H6: There is no statistically significant impact at $(\alpha \leq 0.05)$ that sound corpo- 
rate governance practices in their wider and all-inclusive context (transparency, equality and justice, accountability, participation, integrity) have been implemented in assessing job satisfaction in its wider and all-inclusive context (salaries and compensation packages, relationship with immediate supervisor, training and professional development, promotion, performance evaluation) by public sector workers in Jordan.

\section{Research Objectives}

Based on the research problem and its importance, this study aims to achieve the following objectives:

1) Identify the extent to which the principles of good governance in its dimensions is applied to the public sector in Jordan.

2) Identify the level of job satisfaction with its dimensions among public sector employees in Jordan.

3) Identify the effect of applying good governance principles in achieving job satisfaction among public sector employees in Jordan.

\section{Research Importance}

The research's importance lies in the importance of its variables and expected benefit by government sector institutions from the study. What makes this study especially important is the limited number of researches that dealt with the effect of principles of good governance on achieving job satisfaction among public sector employees in general, and in Jordan in particular. In addition, this study deals with a very important topic; that is good governance, especially since many international organizations began to pay attention to the topic, given the breaches and violations the world has witnessed in the public and private sectors. AS well, this study deals with another topic, job satisfaction, which has been receiving more attention recently despite being an old topic, given the importance of the human resources in achieving organizational goals.

\section{Research Methodology}

\subsection{Research Approach}

This study is a descriptive causal one, where the descriptive analytical approach was followed. It is a descriptive study because it describes the reality and level of application of the principles of good governance, as well as the reality (job satisfaction levels) of employees in public sector institutions in Jordan. It is also an analytical study, as it studies the impact of applying the principles of good governance on job satisfaction among employees in the public sector in Jordan.

\subsection{Statistical Methods Used}

In order to test the hypotheses of the study and arrive at the results and recom- 
mendations that achieve the research objectives, appropriate statistical methods were used to examine the hypotheses. Multiple Regression Analysis methods were used, as well as Descriptive statistical methods for extracting the means of the study sample answers on the study questions, in addition to using standard deviations.

\subsection{Research Population and Sample}

The research population consisted of all the public sector employees subject to the civil service system, 219,000 employees. The analysis and sampling unit included all working groups in the government sector (Secretary General/Director General, Secretary General Assistant/General Director Assistant, Director of Directorate, Head of Department/Division/Unit, employee). The sample of the study was identified with 384 individuals (Sekaran and Bougie, 2016), and hence 384 questionnaires were distributed, of which 315 questionnaires were returned after excluding 7 questionnaires that are not suitable for analysis. Therefore, the number of questionnaires valid for statistical analysis was 308, noting that the study sample was a stratified random sample.

\section{Description Sample Characteristics}

This section of the study aims to explain the personal and job characteristics of the study sample in terms of gender, academic qualifications, job title, in the public sector. The following Table 1 shows the research sample answers about personal and job characteristics.

Table 1 shows that $64.9 \%$ of the sample are males and the rest are females. In addition, it is found that $54.5 \%$ of the sample has a bachelor's degree followed by those who have a master's degree. As for the job title, it is found that $49.7 \%$ of the sample is working as employees, followed by those who are working as Head of the Department.

\subsection{Research Tools}

This study relied on two main sources to collect the required data: the secondary sources, as well as the primary sources represented by the questionnaire that was specifically designed for the purposes of the research. The design of the study tool (the questionnaire), was based on previous literature, where the dimensions of good governance as well as job satisfaction, were determined through those studies. Afterwards, the study sample was surveyed to find out the most important dimensions for the survey takers. The dimensions related to good governance were: Transparency, Equality and Justice, Accountability, Participation, and Integrity, whereas Salaries and Compensation Packages, Immediate Supervisors, Training Programs, Promotion, and Performance Evaluation were the dimensions related to job satisfaction. After determining these dimensions, the researcher constructed the paragraphs of the questionnaire. 
Table 1. The research sample answers about personal and job characteristics in terms of gender, Academic qualifications, and job title.

\begin{tabular}{|c|c|c|c|c|c|}
\hline \multicolumn{2}{|r|}{ Gender } & \multirow{2}{*}{$\begin{array}{c}\text { Frequency } \\
108\end{array}$} & \multirow{2}{*}{$\begin{array}{c}\text { Percent } \\
35.1\end{array}$} & \multirow{2}{*}{$\begin{array}{c}\begin{array}{c}\text { Valid } \\
\text { Percent }\end{array} \\
35.1\end{array}$} & \multirow{2}{*}{$\begin{array}{c}\begin{array}{c}\text { Cumulative } \\
\text { Percent }\end{array} \\
35.1\end{array}$} \\
\hline & Female & & & & \\
\hline \multirow[t]{2}{*}{ Valid } & Male & 200 & 64.9 & 64.9 & 100.0 \\
\hline & Total & 308 & 100.0 & 100.0 & \\
\hline \multicolumn{2}{|r|}{ Academic qualifications } & Frequency & Percent & $\begin{array}{l}\text { Valid } \\
\text { Percent }\end{array}$ & $\begin{array}{l}\text { Cumulative } \\
\text { Percent }\end{array}$ \\
\hline \multirow{6}{*}{ Valid } & $\mathrm{Ba}$ & 168 & 54.5 & 54.5 & 54.5 \\
\hline & Diploma and less & 22 & 7.1 & 7.1 & 61.7 \\
\hline & Ph.D. & 24 & 7.8 & 7.8 & 69.5 \\
\hline & Master & 94 & 30.5 & 30.5 & 100.0 \\
\hline & Total & 308 & 100.0 & 100.0 & \\
\hline & Job title & Frequency & Percent & $\begin{array}{l}\text { Valid } \\
\text { Percent }\end{array}$ & $\begin{array}{c}\text { Cumulative } \\
\text { Percent }\end{array}$ \\
\hline \multirow{6}{*}{ Valid } & $\begin{array}{c}\text { Secretary General/General } \\
\text { Director }\end{array}$ & 3 & 1.0 & 1.0 & 1.0 \\
\hline & Head of the Department & 98 & 31.8 & 31.8 & 32.8 \\
\hline & Directorate Director & 36 & 11.7 & 11.7 & 44.5 \\
\hline & $\begin{array}{c}\text { Assistant of Secretary } \\
\text { General/General Director }\end{array}$ & 18 & 5.8 & 5.8 & 50.3 \\
\hline & Employee & 153 & 49.7 & 49.7 & 100.0 \\
\hline & Total & 308 & 100.0 & 100.0 & \\
\hline
\end{tabular}

The questionnaire consisted of 87 sections designed to measure the dimensions of the independent and dependent variables within two parts:

- The first part: Personal data of the study sample (gender, academic qualifications, job title).

- The second part: The research focus, and it consisted of 59 sections covering the dimensions of corporate governance (transparency, justice and equality, accountability, participation, integrity) in addition to 27 sections covering the dimensions of job satisfaction (salaries and compensation, relationship with immediate supervisor, training and professional development, promotion, performance evaluation). The variables were measured using the five-point Likert scale.

\subsection{Normal Distribution Test}

Multicollinearity between independent variables was tested as shown in Table 2. It is found that VIF values are less acceptable cutoff values (10). Whereas the 
Tolerance values are less than the acceptable cutoff value (0.10).

\subsection{Validity and Reliability of Research Tools}

In order to test the validity of the research tools, the questionnaire was presented to a number of specialized arbitrators in order to ensure the clarity and the understandability of the sections contained therein, and the required modifications were made.

Cronbach Alpha was used to test the consistency of the questionnaire. Table 3 shows that Alpha value for each variable is greater than the accepted value $(0.60)$ that reflects the consistency of the questionnaire (Sekaran \& Bougie, 2016).

\subsection{Research Variables}

The study consisted of two variables:

The independent variable, which is corporate governance in its dimensions (transparency, justice and equality, accountability, participation, integrity).

Table 2. Collinearity statistics test.

\begin{tabular}{ccc}
\hline & \multicolumn{2}{c}{ Collinearity Statistics } \\
\cline { 2 - 3 } Model & Tolerance & VIF \\
\hline Transparency & 0.246 & 4.057 \\
equality and justice & 0.217 & 4.617 \\
Accountability & 0.126 & 7.915 \\
Participation & 0.246 & 4.063 \\
Integrity & 0.150 & 6.655 \\
\hline
\end{tabular}

Table 3. Consistency of research tools.

\begin{tabular}{cc}
\hline Variable & Alpha value \\
\hline Transparency & 0.947 \\
equality and justice & 0.919 \\
Accountability & 0.953 \\
Participation & 0.894 \\
Integrity & 0.933 \\
salaries and compensation packages & 0.857 \\
relationship with immediate supervisor & 0.949 \\
training and professional development & 0.914 \\
Promotion & 0.915 \\
performance evaluation & 0.936
\end{tabular}


The dependent variable, which is job satisfaction in its dimensions (salaries and compensation, relationship with the immediate supervisor, training and professional development, promotion, performance evaluation).

\section{Data Analysis and Results}

Mean and standard deviation were used to describe attitudes toward following questions:

\subsection{Corporate Governance Practices}

Table 4 shows that there are positive attitudes toward the above variable since its mean is greater than the mean of the scale (3). Also is found that there are negative attitudes toward $\mathrm{Q}(8,9,12,15,16)$ since their means are less than the mean of the scale, whereas, there are positive attitudes toward the rest of questions because their means are above mean of the scale (3).

Table 4. Descriptive statistics (transparency).

\begin{tabular}{|c|c|c|c|c|c|}
\hline Transparency & $\mathrm{N}$ & Minimum & Maximum & Mean & Std. Deviation \\
\hline $\mathrm{q} 1$ & 308 & 1 & 5 & 3.07 & 1.036 \\
\hline $\mathrm{q} 2$ & 308 & 1 & 5 & 3.63 & 0.951 \\
\hline q3 & 308 & 1 & 5 & 3.42 & 1.041 \\
\hline $\mathrm{q} 4$ & 308 & 1 & 5 & 3.57 & 1.064 \\
\hline q5 & 308 & 1 & 5 & 3.55 & 1.043 \\
\hline q6 & 308 & 1 & 5 & 3.55 & 0.885 \\
\hline q7 & 308 & 1 & 5 & 3.54 & 0.999 \\
\hline q8 & 308 & 1 & 5 & 2.92 & 1.129 \\
\hline $\mathrm{q} 9$ & 308 & 1 & 5 & 2.89 & 1.209 \\
\hline $\mathrm{q} 10$ & 308 & 1 & 5 & 3.07 & 1.177 \\
\hline q11 & 308 & 1 & 5 & 3.43 & 1.138 \\
\hline $\mathrm{q} 12$ & 308 & 1 & 5 & 2.85 & 1.052 \\
\hline q13 & 308 & 1 & 5 & 3.21 & 1.072 \\
\hline $\mathrm{q} 14$ & 308 & 1 & 5 & 3.30 & 1.018 \\
\hline q15 & 308 & 1 & 5 & 2.92 & 1.154 \\
\hline q16 & 308 & 1 & 5 & 2.86 & 1.242 \\
\hline $\mathrm{q} 17$ & 308 & 1 & 5 & 3.09 & 1.113 \\
\hline $\mathrm{q} 18$ & 308 & 1 & 5 & 3.25 & 1.089 \\
\hline transparency & 308 & 1.11 & 5.00 & 3.2276 & 0.78513 \\
\hline Valid N (listwise) & 308 & & & & \\
\hline
\end{tabular}


Table 5 shows that there are negative attitudes toward the above variable since its mean is less than the mean of the scale (3). Also is found that there are negative attitudes toward the above questions since their means are less than the mean of the scale.

Table 6 shows that there are positive attitudes toward the above variable since its mean is greater than the mean of the scale (3). Also is found that there are negative attitudes toward $\mathrm{Q}(34,36,37,39,40,42)$ since their means are less than the mean of the scale, whereas, there are positive attitudes toward the rest of questions because their means are above mean of the scale (3).

Table 7 shows that there are negative attitudes toward the above variable since its mean is less than the mean of the scale (3). Also is found that there are negative attitudes toward Q $(45,46,47,49)$ since their means are less than the mean of the scale, whereas, there are positive attitudes toward the rest of questions because their means are above mean of the scale (3).

Table 8 shows that there are negative attitudes toward the above variable since its mean is less than the mean of the scale (3). Also is found that there are negative attitudes toward Q $(51,52,53,54,56,57)$ since their means are less than the mean of the scale, whereas, there are positive attitudes toward the rest of questions because their means are above mean of the scale (3).

\subsection{Job Satisfaction}

Table 9 shows that there are negative attitudes toward the above variable since its mean is less than the mean of the scale (3). Also is found that there are negative attitudes toward the above questions since their means are less than the mean of the scale.

Table 10 shows that there are positive attitudes toward the above variable since its mean is greater than the mean of the scale (3). Also is found that there are negative attitudes toward Q $(67,68)$ since their means are less than the mean of the scale, whereas, there are positive attitudes toward the rest of questions because their means are above mean of the scale (3).

Table 5. Descriptive statistics (equality and justice).

\begin{tabular}{cccccc}
\hline Equality and justice & $\mathrm{N}$ & Minimum & Maximum & Mean & Std. Deviation \\
\hline q19 & 308 & 1 & 5 & 2.60 & 1.169 \\
q20 & 308 & 1 & 5 & 2.62 & 1.178 \\
q21 & 308 & 1 & 5 & 2.48 & 1.084 \\
q22 & 308 & 1 & 5 & 2.92 & 1.259 \\
q23 & 308 & 1 & 5 & 2.59 & 1.176 \\
q24 & 308 & 1 & 5 & 2.51 & 1.134 \\
Equality and justice & 308 & 1.00 & 5.00 & 2.6201 & 0.98505 \\
Valid N (listwise) & 308 & & & & \\
\hline
\end{tabular}


Table 6. Descriptive statistics (accountability).

\begin{tabular}{|c|c|c|c|c|c|}
\hline Accountability & $\mathrm{N}$ & Minimum & Maximum & Mean & Std. Deviation \\
\hline q25 & 308 & 1 & 5 & 3.87 & 0.960 \\
\hline q26 & 308 & 1 & 5 & 3.49 & 1.048 \\
\hline q27 & 308 & 1 & 5 & 3.50 & 0.974 \\
\hline q28 & 308 & 1 & 5 & 3.47 & 0.886 \\
\hline q29 & 308 & 1 & 5 & 3.63 & 1.040 \\
\hline $\mathrm{q} 30$ & 308 & 1 & 5 & 3.52 & 0.960 \\
\hline q31 & 308 & 1 & 5 & 3.69 & 0.976 \\
\hline q32 & 308 & 1 & 5 & 3.17 & 1.169 \\
\hline q33 & 308 & 1 & 5 & 3.34 & 0.991 \\
\hline q34 & 308 & 1 & 5 & 2.87 & 1.084 \\
\hline q35 & 308 & 1 & 5 & 3.05 & 1.271 \\
\hline q36 & 308 & 1 & 5 & 2.50 & 1.099 \\
\hline q37 & 308 & 1 & 5 & 2.52 & 1.125 \\
\hline q38 & 308 & 1 & 5 & 3.03 & 1.067 \\
\hline q39 & 308 & 1 & 5 & 2.75 & 1.167 \\
\hline $\mathrm{q} 40$ & 308 & 1 & 5 & 2.85 & 1.180 \\
\hline q41 & 308 & 1 & 5 & 3.44 & 1.309 \\
\hline $\mathrm{q} 42$ & 308 & 1 & 5 & 2.93 & 1.033 \\
\hline accountability & 308 & 1.33 & 5.00 & 3.2006 & 0.80358 \\
\hline Valid N (listwise) & 308 & & & & \\
\hline
\end{tabular}

Table 7. Descriptive statistics (participation).

\begin{tabular}{cccccc}
\hline Participation & $\mathrm{N}$ & Minimum & Maximum & Mean & Std. Deviation \\
\hline $\mathrm{q} 43$ & 308 & 1 & 5 & 3.37 & 0.876 \\
$\mathrm{q} 44$ & 308 & 1 & 5 & 3.04 & 1.049 \\
$\mathrm{q} 45$ & 308 & 1 & 5 & 2.70 & 1.027 \\
$\mathrm{q} 46$ & 308 & 1 & 5 & 2.95 & 0.955 \\
$\mathrm{q} 47$ & 308 & 1 & 5 & 2.83 & 1.252 \\
$\mathrm{q} 48$ & 308 & 1 & 5 & 3.04 & 1.093 \\
$\mathrm{q} 49$ & 308 & 1 & 5 & 2.83 & 1.037 \\
q50 & 308 & 1 & 5 & 3.19 & 1.189 \\
participation & 308 & 1.00 & 5.00 & 2.9939 & 0.80733 \\
Valid N (listwise) & 308 & & & & \\
\hline
\end{tabular}


Table 8. Descriptive statistics (integrity).

\begin{tabular}{cccccc}
\hline Integrity & $\mathrm{N}$ & Minimum & Maximum & Mean & Std. Deviation \\
\hline q51 & 308 & 1 & 5 & 2.56 & 1.150 \\
q52 & 308 & 1 & 5 & 2.73 & 1.092 \\
q53 & 308 & 1 & 5 & 2.87 & 1.074 \\
q54 & 308 & 1 & 5 & 2.85 & 0.967 \\
q55 & 308 & 1 & 5 & 3.08 & 1.104 \\
q56 & 308 & 1 & 5 & 2.44 & 1.127 \\
q57 & 308 & 1 & 5 & 2.96 & 1.135 \\
q58 & 308 & 1 & 5 & 3.31 & 1.034 \\
q59 & 308 & 1 & 5 & 3.01 & 0.997 \\
integrity & 308 & 1.00 & 5.00 & 2.8694 & 0.86923 \\
Valid N (listwise) & 308 & & & &
\end{tabular}

Table 9. Descriptive statistics (salaries and compensation packages).

\begin{tabular}{cccccc}
\hline $\begin{array}{c}\text { Salaries and compensation } \\
\text { packages }\end{array}$ & $\mathrm{N}$ & Minimum & Maximum & Mean & Std. Deviation \\
\hline q60 & 308 & 1 & 5 & 2.69 & 1.110 \\
q61 & 308 & 1 & 5 & 2.84 & 1.136 \\
q62 & 308 & 1 & 5 & 2.54 & 1.087 \\
q63 & 308 & 1 & 5 & 2.38 & 1.262 \\
q64 & 308 & 1 & 5 & 2.32 & 1.081 \\
q65 & 308 & 1 & 4 & 2.49 & 1.038 \\
Salaries and compensation & 308 & 1.00 & 4.67 & 2.5417 & 0.85640 \\
packages & 308 & & & & \\
Valid N (listwise) & & & & & \\
\hline
\end{tabular}

Table 10. Descriptive statistics (relationship with immediate supervisor).

\begin{tabular}{cccccc}
\hline $\begin{array}{c}\text { Relationship with } \\
\text { immediate supervisor }\end{array}$ & $\mathrm{N}$ & Minimum & Maximum & Mean & Std. Deviation \\
\hline q66 & 308 & 1 & 5 & 3.30 & 1.267 \\
q67 & 308 & 1 & 5 & 2.93 & 1.215 \\
q68 & 308 & 1 & 5 & 2.93 & 1.157 \\
q69 & 308 & 1 & 5 & 3.06 & 1.095 \\
q70 & 308 & 1 & 5 & 3.01 & 1.254 \\
$\begin{array}{c}\text { Relationship with } \\
\text { immediate supervisor }\end{array}$ & 308 & 1.00 & 5.00 & 3.0442 & 1.09372 \\
Valid N (listwise) & 308 & & & & \\
\hline
\end{tabular}


Table 11 shows that there are negative attitudes toward the above variable since its mean is less than the mean of the scale (3). Also is found that there are negative attitudes toward $\mathrm{Q}(72,73,74,75,76)$ since their means are less than the mean of the scale, whereas, there are positive attitudes toward the rest of questions because their means are above mean of the scale (3).

Table 12 shows that there are negative attitudes toward the above variable since its mean is less than the mean of the scale (3). Also is found that there are negative attitudes toward the above questions since their means are less than the mean of the scale.

Table 13 shows that there are negative attitudes toward the above variable since its mean is less than the mean of the scale (3). Also is found that there are negative attitudes toward the above questions since their means are less than the mean of the scale.

Table 11. Descriptive statistics (training and professional development).

\begin{tabular}{|c|c|c|c|c|c|}
\hline $\begin{array}{l}\text { Training and } \\
\text { professional } \\
\text { development }\end{array}$ & $\mathrm{N}$ & Minimum & Maximum & Mean & Std. Deviation \\
\hline $\mathrm{q} 71$ & 308 & 1 & 5 & 3.02 & 1.171 \\
\hline $\mathrm{q} 72$ & 308 & 1 & 5 & 2.90 & 1.111 \\
\hline $\mathrm{q} 73$ & 308 & 1 & 5 & 2.46 & 1.122 \\
\hline $\mathrm{q} 74$ & 308 & 1 & 5 & 2.99 & 1.127 \\
\hline $\mathrm{q} 75$ & 308 & 1 & 4 & 2.68 & 1.106 \\
\hline $\mathrm{q} 76$ & 308 & 1 & 5 & 2.64 & 1.103 \\
\hline Training & 308 & 1.00 & 4.50 & 2.7814 & 0.93935 \\
\hline Valid N (listwise) & 308 & & & & \\
\hline
\end{tabular}

Table 12. Descriptive statistics (promotion).

\begin{tabular}{cccccc}
\hline Promotion & $\mathrm{N}$ & Minimum & Maximum & Mean & Std. Deviation \\
\hline q77 & 308 & 1 & 5 & 2.61 & 1.129 \\
$\mathrm{q} 78$ & 308 & 1 & 5 & 2.72 & 1.125 \\
$\mathrm{q} 79$ & 308 & 1 & 5 & 2.45 & 1.156 \\
q80 & 308 & 1 & 5 & 2.30 & 1.065 \\
Promotion & 308 & 1.00 & 4.75 & 2.5195 & 0.99859 \\
Valid N (listwise) & 308 & & & & \\
\hline
\end{tabular}


Table 13. Descriptive statistics (performance evaluation).

\begin{tabular}{cccccc}
\hline $\begin{array}{c}\text { Performance } \\
\text { evaluation }\end{array}$ & $\mathrm{N}$ & Minimum & Maximum & Mean & Std. Deviation \\
\hline $\mathrm{q} 81$ & 308 & 1 & 5 & 2.77 & 1.056 \\
$\mathrm{q} 82$ & 308 & 1 & 4 & 2.49 & 1.105 \\
$\mathrm{q} 83$ & 308 & 1 & 5 & 2.53 & 1.114 \\
$\mathrm{q} 84$ & 308 & 1 & 5 & 2.58 & 1.117 \\
$\mathrm{q} 85$ & 308 & 1 & 5 & 2.36 & 1.099 \\
q86 & 308 & 1 & 5 & 2.48 & 1.093 \\
Evaluation & 308 & 1.00 & 4.50 & 2.5346 & 0.95467 \\
Valid N (listwise) & 308 & & & & \\
\hline
\end{tabular}

\section{Hypothesis Testing}

$\mathrm{H1}$ : There is no statistically significant impact at $(\alpha \leq 0.05)$ that sound corporate governance practices in their wider and all-inclusive context (transparency, equality and justice, accountability, participation, integrity) have been implemented in setting salaries and compensation packages for public sector workers in Jordan.

\begin{tabular}{|c|c|c|c|c|c|c|}
\hline \multicolumn{7}{|c|}{ Model Summary } \\
\hline \multicolumn{2}{|r|}{ Model } & $\mathrm{R}$ & R Square & \multicolumn{2}{|c|}{$\begin{array}{l}\text { Adjusted } \\
\text { R Square }\end{array}$} & $\begin{array}{l}\text { Std. Error of } \\
\text { the Estimate }\end{array}$ \\
\hline & 1 & $0.521^{\mathrm{a}}$ & 0.271 & 0.2 & & 0.73724 \\
\hline \multicolumn{7}{|c|}{ aPredictors: (Constant), integrity, equality and justice, transparency, participation, accountability. } \\
\hline \multicolumn{7}{|c|}{ ANOVA $^{\mathrm{a}}$} \\
\hline & Model & Sum of Squares & $\mathrm{df}$ & Mean Square & $\mathrm{F}$ & Sig. \\
\hline \multirow{3}{*}{1} & Regression & 61.015 & 5 & 12.203 & 22.452 & $0.000^{\mathrm{b}}$ \\
\hline & Residual & 164.144 & 302 & 0.544 & & \\
\hline & Total & 225.160 & 307 & & & \\
\hline
\end{tabular}

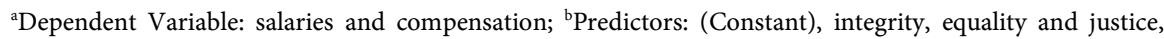
transparency, participation, accountability. 


\begin{tabular}{|c|c|c|c|c|c|}
\hline \multicolumn{6}{|c|}{ Coefficients $^{\mathrm{a}}$} \\
\hline \multirow{2}{*}{ Model } & \multicolumn{2}{|c|}{$\begin{array}{l}\text { Unstandardized } \\
\text { Coefficients }\end{array}$} & \multirow{2}{*}{$\begin{array}{c}\text { Standardized } \\
\text { Coefficients }\end{array}$} & \multirow{2}{*}{$\mathrm{t}$} & \multirow{2}{*}{ Sig. } \\
\hline & B & Std. Error & & & \\
\hline (Constant) & 1.561 & 0.209 & & 7.484 & 0.000 \\
\hline transparency & 0.293 & 0.108 & 0.268 & 2.712 & 0.007 \\
\hline Equality and justice & -0.059 & 0.092 & -0.068 & -0.646 & 0.519 \\
\hline \multicolumn{6}{|l|}{1} \\
\hline accountability & -0.080 & 0.147 & -0.075 & -0.543 & 0.588 \\
\hline participation & -0.598 & 0.105 & -0.564 & -5.692 & 0.000 \\
\hline integrity & 0.780 & 0.125 & 0.791 & 6.242 & 0.000 \\
\hline
\end{tabular}

${ }^{\mathrm{a} D e p e n d e n t ~ V a r i a b l e: ~ s a l a r i e s ~ a n d ~ c o m p e n s a t i o n . ~}$

Multiple Regression is used to test the above hypothesis, it is found that $\mathrm{r}=$ 0.521 reflects a medium significant impact as well as $r^{2}=0.271$ reflects that $27.1 \%$ of the variance in the dependent variable is explained by the independent variable.

Also, it is found that $\mathrm{F}$ value $=22.452$ is significant at 0.05 level that means there is a statistically significant impact at $(\alpha \leq 0.05)$ that sound corporate governance practices in their wider and all-inclusive context (transparency, equality and justice, accountability, participation, integrity) have been implemented in setting salaries and compensation packages for public sector workers in Jordan.

Also, $t$ value for (transparency, integrity, and participation) variables are significant at 0.05 level that means they have impact on the dependent variable.

H2: There is no statistically significant impact at $(\alpha \leq 0.05)$ that sound corporate governance practices in their wider and all-inclusive context (transparency, equality and justice, accountability, participation, integrity) have been implemented in setting the parameters of and managing the relationship between public sector workers and their immediate supervisors in Jordan.

\begin{tabular}{ccccc}
\hline \multicolumn{5}{c}{ Model Summary } \\
\hline Model & $\mathrm{R}$ & R Square & $\begin{array}{l}\text { Adjusted } \\
\text { R Square }\end{array}$ & $\begin{array}{l}\text { Std. Error of } \\
\text { the Estimate }\end{array}$ \\
\hline 1 & $0.585^{\mathrm{a}}$ & 0.342 & 0.331 & 0.89462 \\
\hline
\end{tabular}

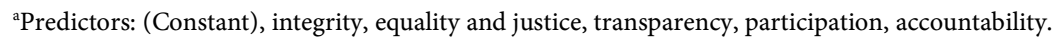




\begin{tabular}{|c|c|c|c|c|c|c|}
\hline & \multicolumn{6}{|c|}{ ANOVA $^{\mathrm{a}}$} \\
\hline & Model & Sum of Squares & $\mathrm{df}$ & Mean Square & $\mathrm{F}$ & Sig. \\
\hline \multirow{3}{*}{1} & Regression & 125.538 & 5 & 25.108 & 31.371 & $0.000^{\mathrm{b}}$ \\
\hline & Residual & 241.702 & 302 & 0.800 & & \\
\hline & Total & 367.239 & 307 & & & \\
\hline
\end{tabular}

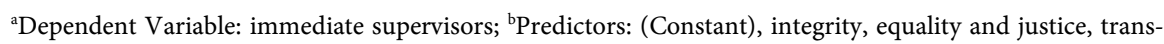
parency, participation, accountability.

\begin{tabular}{|c|c|c|c|c|c|}
\hline \multicolumn{6}{|c|}{ Coefficients $^{a}$} \\
\hline \multirow{2}{*}{ Model } & \multicolumn{2}{|c|}{$\begin{array}{l}\text { Unstandardized } \\
\text { Coefficients }\end{array}$} & \multirow{2}{*}{$\begin{array}{c}\begin{array}{c}\text { Standardized } \\
\text { Coefficients }\end{array} \\
\text { Beta }\end{array}$} & \multirow{2}{*}{$\mathrm{t}$} & \multirow{2}{*}{ Sig. } \\
\hline & B & Std. Error & & & \\
\hline (Constant) & 0.211 & 0.253 & & 0.834 & 0.405 \\
\hline Transparency & 0.190 & 0.131 & 0.136 & 1.449 & 0.148 \\
\hline Equality and justice & -0.399 & 0.111 & -0.360 & -3.585 & 0.000 \\
\hline Accountability & 0.879 & 0.179 & 0.646 & 4.918 & 0.000 \\
\hline Participation & 0.018 & 0.127 & 0.013 & 0.143 & 0.887 \\
\hline integrity & 0.139 & 0.152 & 0.110 & 0.917 & 0.360 \\
\hline
\end{tabular}

${ }^{a}$ Dependent Variable: immediate supervisors.

Multiple Regression is used to test the above hypothesis, it is found that $\mathrm{r}=$ 0.585 reflects a medium significant impact as well as $r^{2}=0.342$ reflects that $34.2 \%$ of the variance in the dependent variable is explained by the independent variable.

Also, it is found that $\mathrm{F}$ value $=10.215$ is significant at 0.05 level that means there is a statistically significant impact at $(\alpha \leq 0.05)$ that sound corporate governance practices in their wider and all-inclusive context (transparency, equality and justice, accountability, participation, integrity) have been implemented in setting the parameters of and managing the relationship between public sector workers and their immediate supervisors in Jordan.

Also, $t$ value for (accountability, equality, and justice) variables is significant at 0.05 level that means they have an impact on the dependent variable.

H3: There is no statistically significant impact at $(\alpha \leq 0.05)$ that sound corporate governance practices in their wider and all-inclusive context (transparency, equality and justice, accountability, participation, integrity) have been implemented in designing and delivering training programs for public sector workers in Jordan. 


\begin{tabular}{ccccc}
\hline \multicolumn{5}{c}{ Model Summary } \\
\hline Model & $\mathrm{R}$ & R Square & $\begin{array}{l}\text { Adjusted } \\
\text { R Square }\end{array}$ & $\begin{array}{c}\text { Std. Error } \\
\text { of the Estimate }\end{array}$ \\
\hline 1 & $0.735^{\mathrm{a}}$ & 0.540 & 0.532 & 0.64245 \\
\hline
\end{tabular}

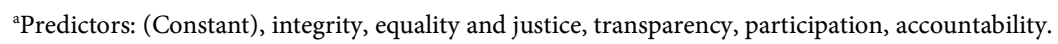

\begin{tabular}{ccccccc}
\hline \multicolumn{7}{c}{ ANOVA $^{\mathrm{a}}$} \\
\hline \multicolumn{1}{c}{ Model } & Sum of Squares & $\mathrm{df}$ & Mean Square & $\mathrm{F}$ & Sig. \\
\hline & Regression & 146.242 & 5 & 29.248 & 70.863 & $0.000^{\mathrm{b}}$ \\
1 & Residual & 124.649 & 302 & 0.413 & & \\
& Total & 270.891 & 307 & & & \\
\hline
\end{tabular}

${ }^{a}$ Dependent Variable: training; ${ }^{b}$ Predictors: (Constant), integrity, equality and justice, transparency, participation, accountability.

\begin{tabular}{|c|c|c|c|c|c|}
\hline \multicolumn{6}{|c|}{ Coefficients $s^{a}$} \\
\hline \multirow[t]{2}{*}{ Model } & \multicolumn{2}{|c|}{$\begin{array}{l}\text { Unstandardized } \\
\text { Coefficients }\end{array}$} & \multirow{2}{*}{$\begin{array}{c}\begin{array}{c}\text { Standardized } \\
\text { Coefficients }\end{array} \\
\text { Beta }\end{array}$} & \multirow[t]{2}{*}{$\mathrm{t}$} & \multirow[t]{2}{*}{ Sig. } \\
\hline & B & Std. Error & & & \\
\hline (Constant) & 0.111 & 0.182 & & 0.613 & 0.540 \\
\hline transparency & 0.818 & 0.094 & 0.684 & 8.699 & 0.000 \\
\hline Equality and justice & -0.031 & 0.080 & -0.033 & -0.389 & 0.697 \\
\hline accountability & -0.091 & 0.128 & -0.078 & -0.706 & 0.481 \\
\hline participation & -0.187 & 0.092 & -0.161 & -2.042 & 0.042 \\
\hline integrity & 0.335 & 0.109 & 0.310 & 3.075 & 0.002 \\
\hline
\end{tabular}

${ }^{\mathrm{a} D e p e n d e n t ~ V a r i a b l e: ~ t r a i n i n g . ~}$

Multiple Regression is used to test the above hypothesis, it is found that $\mathrm{r}=$ 0.735 reflects a high significant impact as well as $\mathrm{r}^{2}=0.54$ reflects that $54 \%$ of the variance in the dependent variable is explained by the independent variable.

Also, it is found that $\mathrm{F}$ value $=70.863$ is significant at 0.05 level that means there is a statistically significant impact at $(\alpha \leq 0.05)$ that sound corporate governance practices in their wider and all-inclusive context (transparency, equality and justice, accountability, participation, integrity) have been implemented in designing and delivering training programs for public sector workers in Jordan.

Also, $t$ value for (transparency, participation, Integrity) variables is significant at 0.05 level that means they have impact on the dependent variable.

H4: There is no statistically significant impact at $(\alpha \leq 0.05)$ that sound corpo- 
rate governance practices in their wider and all-inclusive context (transparency, equality and justice, accountability, participation, integrity) have been implemented in the promotion of public sector workers in Jordan.

\begin{tabular}{ccccc}
\hline \multicolumn{5}{c}{ Model Summary } \\
\hline Model & $\mathrm{R}$ & R Square & $\begin{array}{l}\text { Adjusted } \\
\text { R Square }\end{array}$ & $\begin{array}{l}\text { Std. Error of } \\
\text { the Estimate }\end{array}$ \\
\hline 1 & $0.760^{\mathrm{a}}$ & 0.578 & 0.571 & 0.65415 \\
\hline
\end{tabular}

${ }^{a}$ Predictors: (Constant), integrity, equality and justice, transparency, participation, accountability.

\begin{tabular}{ccccccc}
\hline \multicolumn{7}{c}{ ANOVA $^{\mathrm{a}}$} \\
\hline & Model & Sum of Squares & $\mathrm{df}$ & Mean Square & $\mathrm{F}$ & Sig. \\
\hline & Regression & 176.903 & 5 & 35.381 & 82.682 & $0.000^{\mathrm{b}}$ \\
1 & Residual & 129.230 & 302 & 0.428 & & \\
& Total & 306.133 & 307 & & & \\
\hline
\end{tabular}

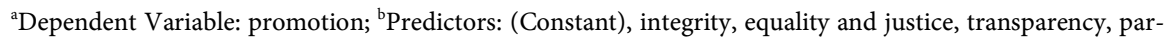
ticipation, accountability.

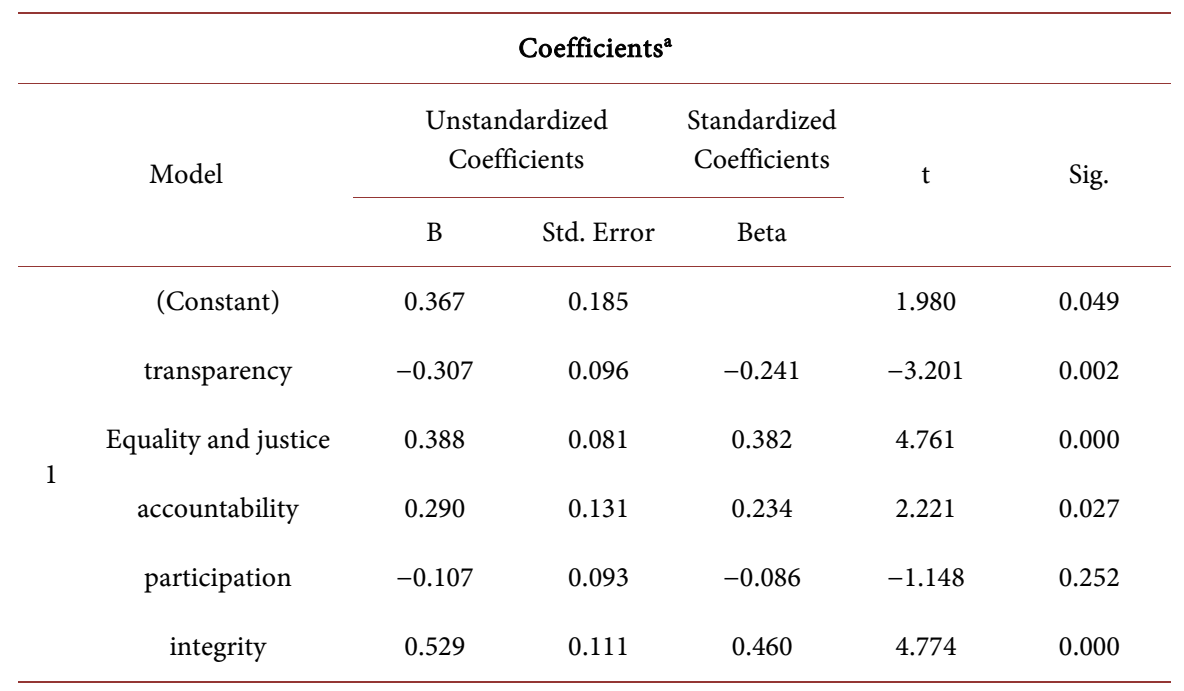

${ }^{\mathrm{a} D e p e n d e n t ~ V a r i a b l e: ~ p r o m o t i o n . ~}$

Multiple Regression is used to test the above hypothesis, it is found that $\mathrm{r}=$ 0.76 reflects a high significant impact as well as $\mathrm{r}^{2}=0.578$ reflects that $57.8 \%$ of the variance in the dependent variable is explained by the independent variable.

Also, it is found that $\mathrm{F}$ value $=82.682$ is significant at 0.05 level that means there is a statistically significant impact at $(\alpha \leq 0.05)$ that sound corporate governance practices in their wider and all-inclusive context (transparency, equality and justice, accountability, participation, integrity) have been implemented in the promotion of public sector workers in Jordan. 
Also, $t$ value for (integrity, transparency, accountability and equality and justice) variables is significant at 0.05 level that means they have impact on the dependent variable.

H5: There is no statistically significant impact at $(\alpha \leq 0.05)$ that sound corporate governance practices in their wider and all-inclusive context (transparency, equality and justice, accountability, participation, integrity) have been implemented in the performance evaluation of public sector workers in Jordan.

\begin{tabular}{ccccc}
\hline \multicolumn{5}{c}{ Model Summary } \\
\hline Model & $\mathrm{R}$ & R Square & $\begin{array}{l}\text { Adjusted } \\
\text { R Square }\end{array}$ & $\begin{array}{c}\text { Std. Error of } \\
\text { the Estimate }\end{array}$ \\
\hline 1 & $0.729^{\mathrm{a}}$ & 0.531 & 0.524 & 0.65884 \\
\hline
\end{tabular}

aPredictors: (Constant), integrity, equality and justice, transparency, participation, accountability.

\begin{tabular}{ccccccc}
\hline \multicolumn{7}{c}{ ANOVA $^{\mathrm{a}}$} \\
\hline \multicolumn{1}{c}{ Model } & Sum of Squares & $\mathrm{df}$ & Mean Square & $\mathrm{F}$ & Sig. \\
\hline & Regression & 148.710 & 5 & 29.742 & 68.520 & $0.000^{\mathrm{b}}$ \\
1 & Residual & 131.088 & 302 & 0.434 & & \\
& Total & 279.797 & 307 & & & \\
\hline
\end{tabular}

${ }^{\mathrm{a} D e p e n d e n t ~ V a r i a b l e: ~ e v a l u a t i o n ; ~}{ }^{\mathrm{b}}$ Predictors: (Constant), integrity, equality and justice, transparency, participation, accountability.

\begin{tabular}{|c|c|c|c|c|c|}
\hline \multicolumn{6}{|c|}{ Coefficients $^{\mathrm{a}}$} \\
\hline \multirow[t]{2}{*}{ Model } & \multicolumn{2}{|c|}{$\begin{array}{l}\text { Unstandardized } \\
\text { Coefficients }\end{array}$} & \multirow{2}{*}{$\begin{array}{c}\begin{array}{c}\text { Standardized } \\
\text { Coefficients }\end{array} \\
\text { Beta }\end{array}$} & \multirow[t]{2}{*}{$\mathrm{t}$} & \multirow[t]{2}{*}{ Sig. } \\
\hline & B & Std. Error & & & \\
\hline (Constant) & -0.045 & 0.186 & & -0.239 & 0.811 \\
\hline transparency & -0.062 & 0.096 & -0.051 & -0.641 & 0.522 \\
\hline Equality and justice & 0.071 & 0.082 & 0.074 & 0.869 & 0.386 \\
\hline accountability & 0.524 & 0.132 & 0.441 & 3.980 & 0.000 \\
\hline participation & 0.039 & 0.094 & 0.033 & 0.413 & 0.680 \\
\hline integrity & 0.279 & 0.112 & 0.254 & 2.497 & 0.013 \\
\hline
\end{tabular}

${ }^{\mathrm{a} D e p e n d e n t ~ V a r i a b l e: ~ e v a l u a t i o n . ~}$

Multiple Regression is used to test the above hypothesis, it is found that $\mathrm{r}=$ 0.729 reflects a high significant impact as well as $r^{2}=0.531$ reflects that $53.1 \%$ of the variance in the dependent variable is explained by the independent variable.

Also, it is found that $\mathrm{F}$ value $=68.520$ is significant at 0.05 level that means 
there is a statistically significant impact at $(\alpha \leq 0.05)$ that sound corporate governance practices in their wider and all-inclusive context (transparency, equality and justice, accountability, participation, integrity) have been implemented in the performance evaluation of public sector workers in Jordan.

Also, $t$ value for (integrity and accountability) variables is significant at 0.05 level that means they have impact on the dependent variable.

H6: There is no statistically significant impact at $(\alpha \leq 0.05)$ that sound corporate governance practices in their wider and all-inclusive context (transparency, equality and justice, accountability, participation, integrity) have been implemented in assessing job satisfaction in its wider and all-inclusive context (salaries and compensation packages, relationship with immediate supervisor, training and professional development, promotion, performance evaluation) by public sector workers in Jordan.

\begin{tabular}{ccccc}
\hline \multicolumn{5}{c}{ Model Summary } \\
\hline Model & $\mathrm{R}$ & R Square & $\begin{array}{l}\text { Adjusted } \\
\text { R Square }\end{array}$ & $\begin{array}{c}\text { Std. Error of } \\
\text { the Estimate }\end{array}$ \\
\hline 1 & $0.816^{\mathrm{a}}$ & 0.665 & 0.660 & 0.42312 \\
\hline
\end{tabular}

aPredictors: (Constant), integrity, equality and justice, transparency, participation, accountability.

\begin{tabular}{cccccc}
\hline \multicolumn{7}{c}{ ANOVA $^{\mathrm{a}}$} \\
\hline Model & Sum of Squares & $\mathrm{df}$ & Mean Square & F & Sig. \\
\hline Regression & 107.517 & 5 & 21.503 & 120.112 & $0.000^{\mathrm{b}}$ \\
Residual & 54.066 & 302 & 0.179 & & \\
Total & 161.583 & 307 & & & \\
\hline
\end{tabular}

${ }^{a}$ Dependent Variable: Satisfaction; ${ }^{\mathrm{b}}$ Predictors: (Constant), integrity, equality and justice, transparency, participation, accountability.

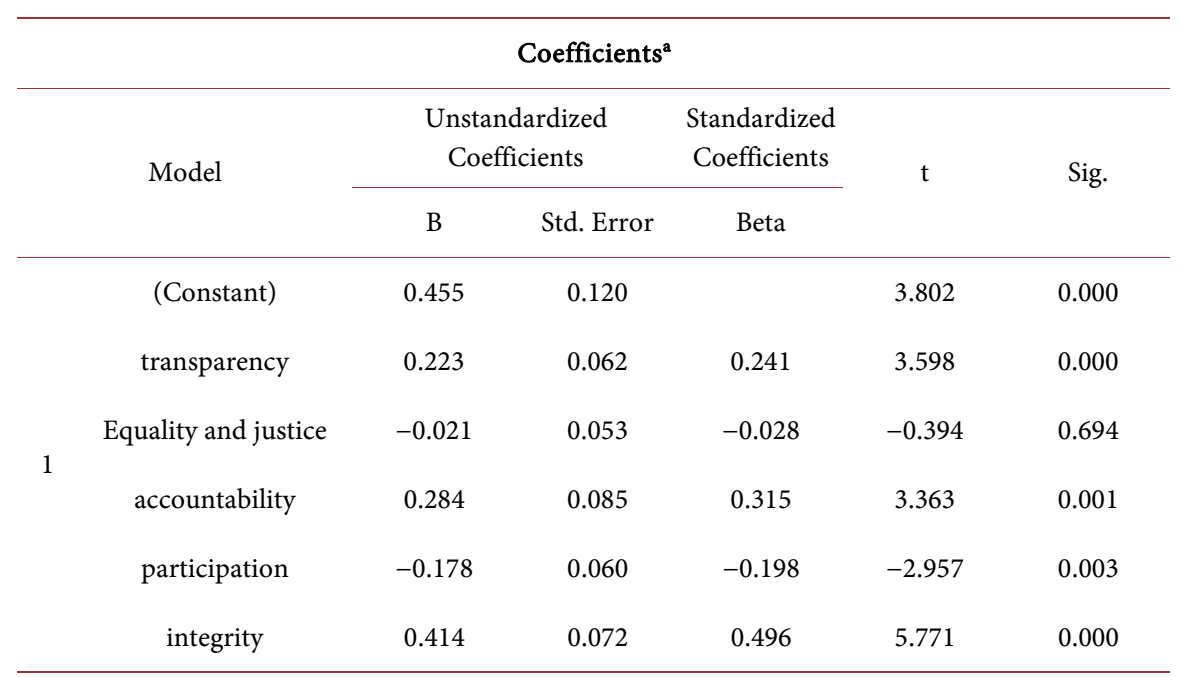

${ }^{a}$ Dependent Variable: Satisfaction. 
Multiple Regression is used to test the above hypothesis, it is found that $\mathrm{r}=$ 0.816 reflects a high significant impact as well as $r^{2}=0.665$ reflects that $66.5 \%$ of the variance in the dependent variable is explained by the independent variable.

Also, it is found that $\mathrm{F}$ value $=120.112$ is significant at 0.05 level that means there is a statistically significant impact at $(\alpha \leq 0.05)$ that sound corporate governance practices in their wider and all-inclusive context (transparency, equality and justice, accountability, participation, integrity) have been implemented in assessing job satisfaction in its wider and all-inclusive context (salaries and compensation packages, relationship with immediate supervisor, training and professional development, promotion, performance evaluation) by public sector workers in Jordan.

Also, $t$ value for (integrity, transparency, accountability, participation) variables is significant at 0.05 level that means it has an impact on the dependent variable.

\section{Results Discussion}

The results indicated that there were negative trends among employees in the public sector in Jordan regarding the extent of applying good governance principles (justice and equality, participation, integrity), while there were positive trends regarding the application of (transparency and accountability) principles. The results also indicated the existence of a statistically significant effect of applying the principles of good governance collectively in each dimension of job satisfaction solely, but to varying degrees. It was also found that there is a statistically significant effect of applying good governance principles collectively on job satisfaction in its combined dimensions. This can be explained by the fact that the concept of good governance in the public sector is still new, not only in Jordan, but also for the vast majority of world countries. Consequently, the effective application of this concept in all its dimensions requires more time, will, and education and awareness processes. As for the positive trends towards the two dimensions (transparency and accountability), it is due to the issuance of the (Right to Information Law), which grants citizens the right to obtain any information they wish to see, as well as strengthening the role of the Integrity and Anti-Corruption Commission and the Audit Bureau, regarding enforcing audits and accountability activities at all functional levels in all fields in the public sector in Jordan.

As for the dependent variable (job satisfaction), results indicated the existence of negative trends among employees in the public sector in Jordan towards (salaries and compensation, training programs, promotion, and performance evaluation) while the respondents 'attitudes were positive with regard to (immediate supervision), and the relationship with the direct managers. The negative trends can be explained by the lack of effective implementation of the (Civil Service Code) that controls the affairs of human resources management in the public sector. As for the positive trends towards (immediate supervision), it can be ex- 
plained as the nature of the Jordanian society culture, including its composition that helps creating this kind of positivity.

\section{Conclusion}

This study aimed to investigate the effect of applying the principles of good governance on job satisfaction among employees in public sector institutions in Jordan. As a result of testing the hypothesis, this study found that the application of good governance principles positively affects job satisfaction, which is consistent with previous studies such as (Nmai \& Dell, 2014; Lakshika \& Priyanath, 2018; Belhadef \& Bouzain, 2019). The study also believes that more efforts are needed by all parties to increase awareness of the importance of good governance principles, the thing that will positively affect its application in terms of increasing the level of job satisfaction among employees.

\section{Recommendations}

Based on the results achieved, the study recommends the following:

1) Increasing awareness of good governance concept, its importance, and its benefits by holding awareness programs, seminars, and training courses for all public sector employees in Jordan.

2) Creating a special course on good governance in Jordanian public and private universities.

3) Updating and activating the guide on good governance issued by the Jordanian Government in 2014.

4) Developing the good governance standard for the King Abdullah II Award for Government Performance Excellence and Transparency.

5) Strengthening the role of government agencies that contribute to promoting the principles of good governance in the public sector (Audit Bureau, Integrity and Anti-Corruption Commission, Civil Service Bureau, Ministry of Justice).

6) Developing and activating the (Civil Service Code), especially with regards to employee training, development, promotion, and performance evaluation.

\section{Conflicts of Interest}

The author declares no conflicts of interest regarding the publication of this paper.

\section{References}

Adeogun, S. O., Abiona, B. G., Ogunjobi, I. O., \& Akano, T. B. (2017). Perceived Effect of Governance Change on Job Satisfaction of Employee in Ogun State Ministry of Agriculture Abeokuta, Ogun State, Nigeria. Ife Journal of Agriculture, 29, 18-27.

Alamrew, Y., Belay, H., \& Shishigu, A. D. (2016). The Effect of Governance on Employees' Job Satisfaction, Intention to Leave and Task Performance (A Case of University of Gondar). Research Journal of Commerce \& Behavioural Sciences, 6, 1-6.

Ali, M. (n/a). Governance and Good Governance: A Conceptual Perspective. The Dialo- 
gue, 10, 66-77.

Belhadef, S., \& Bouzian, O. (2019). Corporate Governance and Its Effective Role in Achieving Job Satisfaction. Al Bashaer Economic Journal, 5, 570-583.

Bordbar, G., \& Saraji, M. K. (2017). The Effect of Corporate Governance on Employee Voice. Global Journal of Scientific Research, 5, 96-101.

Bouckaert, G., \& Van de Walle, S. (2003). Comparing Measures of Citizen Trust and User Satisfaction as Indicators of Good Governance: Difficulties in Linking Trust and Satisfaction Indicators. International Review of Administrative Sciences, 69, 329-343. https://doi.org/10.1177/0020852303693003

Brinkerhoff, D. W., \& Brinkerhoff, J. M. (2015). Public Sector Management Reform in Developing Countries: Perspectives beyond NPM Orthodoxy. Public Administration and Development, 35, 222-237. https://doi.org/10.1002/pad.1739

Butler, M. (2019). Modern Governance in the Public Sector. London: Good Governance Institute Development and Research LLP.

Channuwong, S. (2018). The Relationship between Good Governance Principles and Organizational Justice: A Case Study of Bangkok Government Officials. Asia-Pacific Social Science Review, 18, 43-56.

Cinar, O., \& Karcioglu, F. (2012). The Level of Job Satisfaction in Public Sector: A Survey Study in the Province of Agri, Eastern Anatolia, Turkey. Economics and Management, 17, 712-718. https://doi.org/10.5755/j01.em.17.2.2203

De Nisi, A. S., \& Pritchard, R. D. (2006). Performance Appraisal, Performance Management and Improving Individual Performance: A Motivational Framework. Management and Organization Review, 2, 253-277. https://doi.org/10.1111/j.1740-8784.2006.00042.x

Eslami, J., \& Gharakhani, D. (2012). Organizational Commitment and Job Satisfaction. ARPN Journal of Sciences and Technology, 2, 85-91.

Fardaus, A., \& Khan, M. R. (2006). Good Governance: Bangladesh Perspective. The Social Sciences, 1, 91-97.

Gavriluta (Vatamanu), A. F., \& Lotos, C.-V. (2018). Good Governance and the Rule of Law-Major Pillars of Economic Efficiency. Journal of Public Administration, Finance and Law, No. 13, 123-133.

Grindle, M. S. (2007). Good Enough Governance Revisited. Development Policy Review, 25, 553-574. https://doi.org/10.1111/j.1467-7679.2007.00385.x

Idowu, A. O. (2017). Effectiveness of Performance Appraisal System and Its Effect on Employee Motivation. Nile Journal of Business and Economics, 3, 15-39. https://doi.org/10.20321/nilejbe.v3i5.88

Jamaiudin, N. (2019). Good Governance in Malaysia: Assessing Public Perceptions on the Implementation of National Transformation Policy: 2011-2016. Intellectual Discourse, Special Issue, 719-743.

Juiz, C., Guerrero, C., \& Lera, I. (2014). Implementing Good Governance Principles for the Public Sector in Information Technology: Governance Framework. Open Journal of Accounting, 3, 9-27. https://doi.org/10.4236/ojacct.2014.31003

Kamal, M., \& Batool, S. (2020). Institutional Failure: A Challenge to Good Governance in Pakistan. A Research Journal of South Asian Studies, 35, 101-118.

Kaplan, A. D., Dominis, S., Palen, J. G. H., \& Quain, E. E. (2013). Human Resource Governance: What Does Governance Mean for the Health Workforce in Low- and Middle-Income Countries? Human Resources for Health, 11, 1-12. 
https://doi.org/10.1186/1478-4491-11-6

Karolidis, D., \& Vouzas, F. (2019). From PSM to Helping Behavior in the Contemporary Greek Public Sector: The Roles of Organizational Identification and Job Satisfaction. Public Performance and Management Review, 42, 1418-1447. https://doi.org/10.1080/15309576.2019.1592762

Khudir, I. M., \& Ali, S. (2019). Elements, Characteristics and Principles for Effectiveness Governance in Public Sector. Indian Journal of Science and Technology, 12, 1-9. https://doi.org/10.17485/ijst/2019/v12i36/147260

Kumari, G., \& Pandey, K. M. (2011). Job Satisfaction in Public Sector and Private Sector: A Comparison. International Journal of Innovation, Management and Technology, 2, 222-228.

Lakshika, L. P. C., \& Priyanath, H. M. S. (2018). Effect of Relational Governance on Job Satisfaction: Empirical Evidence of Supportive Staff of the Sabaragamuwa University of Sri Lanka. American Journal of Humanities and Social Sciences Research (AJHSSR), 2, 163-169.

Lezar, M. (2019). The Job Satisfaction of Public Sector Employees in the Arab Countries: A Field Study on a Sample of Participants in the Training Programs Organized by the Arab Planning Institute. Journal of Development and Economic Policies, 21, 53-85.

Malik, M. E., Nawab, S., Naeem, B., \& Danish, R. Q. (2010). Job Satisfaction and Organizational Commitment of University Teachers in Public Sector of Pakistan. International Journal of Business and Management, 5, 17-26. https://doi.org/10.5539/ijbm.v5n6p17

Matei, A., \& Drumasu, C. (2015). Corporate Governance and Public Sector Entities. Procedia Economics and Finance, 26, 495-504. https://doi.org/10.1016/S2212-5671(15)00879-5

Mazhar, M. S., \& Goraya, N. (2015). Issues of Good Governance in South Asia. A Research Journal of South Asian Studies, 30, 125-160.

Ministry of Public Sector Development (2014). Guide to Governance Practices in Public Sector.

Naveed, T. A. (1998). Problems of Good Governance in South Asian Countries: Learning from European Political Models. Karachi: Area Study Center for Europe, B. C. C. \& T. Press.

Nda, M. M., \& Fard, R. Y. (2013). The Impact of Employee Training and Development on Employee Productivity. Global Journal of Commerce \& Management Perspective, 2, 91-93.

Nmai, B. N., \& Delle, E. (2014). Good Corporate Governance and Employee Job Satisfaction: Empirical Evidence from the Ghanaian Telecommunication Sector. International Journal of Humanities and Social Science, 4, 209-217.

Oshilim, N. G., \& Akpesiri, O. P. (2015). Governance, Employee Engagement and Improved Productivity in the Public Sector: The Nigerian Experience. Journal of Investment and Management, 4, 141-151. https://doi.org/10.11648/j.jim.20150405.12

Papachristou, G. K., \& Papachristou, M. K. (2014). The Worthiness of Corporate Governance in Public Sector: The Case of Public Health Care Sector in Greece. Corporate Ownership \& Control, 12, 490-501. https://doi.org/10.22495/cocv12i1c5p4

Perry, L., \& Wise, R. (1990). The Motivational Bases of Public Service. Public Administration Review, 50, 367-373. https://doi.org/10.2307/976618

Pushpika, P. P. G. T. (2019). The Effect of Organizational Commitment and Job Satisfaction on Organizational Citizenship Behavior of the Academic Staff Members in Public 
Sector Universities in Sri Lanka. International Journal of Recent Advances in organizational Behaviour and Decision Sciences (IJRAOB), 5, 1233-1239.

Qureshi, M. S., \& Bin Ab Hamid, K. (2017). Impact of Supervisor Support on Job Satisfaction: A Moderating Role of Fairness Perception. International Journal of Academic Research in Business and Social Sciences, 7, 235-242.

Raheja, K. (2015). Methods of Training and Development. Innovative Journal of Business and Management, 4, 35-41. https://doi.org/10.15520/ijbm.vol4.iss2.17.pp35-41

Ramakant, R. (2003). Good Governance: Modern Global and Regional Perspective (pp. 10-11). New Delhi: MG. Kaniska Publisher Distributors.

Safadi, N. S., Easton, S. D., Wang, Y., Hasson III, R. G., \& Crea, T. M. (2019). Life and Job Satisfaction among Public-Sector Social Workers in the Occupied Palestine Territory. Human Service Organizations: Management, Leadership \& Governance, 43, 41-53. https://doi.org/10.1080/23303131.2018.1564714

Sandika, A., Rupasena, L. P., \& Abeywickrama, L. M. (2016). Effect of Good Governance Perception towards Job Satisfaction: A Case Study of the Agriculture Professionals Attached to the Department of Agriculture Sri Lanka. Tropical Agricultural Research \& Extension, 19, 255-273. https://doi.org/10.4038/tare.v19i3-4.5357

Sekaran, U., \& Bougie, R. (2016). Research Methods for Business: A Skill Building Approach (7th ed.). Hoboken, NJ: Wiley.

Shafi, M. (2004). The Importance of Effective Corporate Governance.

https://papers.ssrn.com

https://doi.org/10.2139/ssrn.617101

Shahin, M. (2016). The Effect of Good Governance Mixture in Governmental Organizations on Promotion of Employees Job Satisfaction (Case Study: Employees and Faculty Members of Lorestan University). Asian Social Science, 12, 108-117. https://doi.org/10.5539/ass.v12n5p108

Sukdeo, S., Lynch, J., Zulu, T., \& Govender, P. (2017). The Influence of Corporate Governance on Employee Welfare. Corporate Ownership \& Control, 14, 196-204. https://doi.org/10.22495/cocv14i4c1art2

Van Dijk, D., \& Schodl, M. (2015). Performance Appraisal and Evaluation. http://www.researchgate.net

Voon, M. L., Lo, M. C., Ngui, K. S., \& Ayob, N. B. (2011). The Influence of Leadership Styles on Employees' Job Satisfaction in Public Sector Organizations in Malaysia. International Journal of Business, Management and Social Sciences, 2, 24-32. 